\title{
Thermal and Chemical Exhaust Gas Recirculation Potential of Punnai Oil Biodiesel Fuelled Diesel Engine For Environmental Sustainability
}

Chidambaranathan Bibin ( $\nabla$ drcbibin@gmail.com )

RMK College of Engineering and Technology https://orcid.org/0000-0002-0252-7709

Ponnusamy Kumarasami Devan

RMK College of Engineering and Technology Department of Mechanical Engineering

Raghavan Sheeja

Easwari Engineering College

Sundaram Madhu

Saveetha School of Engineering

\section{Research Article}

Keywords: Punnai oil biodiesel, Combustion, performance, emissions, EGR, Diesel Engine

Posted Date: February 17th, 2022

DOI: https://doi.org/10.21203/rs.3.rs-1266110/v1

License: (c) (i) This work is licensed under a Creative Commons Attribution 4.0 International License. Read Full License 


\section{Abstract}

Pollution from diesel engines affects negatively the environment. As a result, there is a worldwide concern about reducing the pollutants emitted by diesel engines. In comparison to diesel fuel, biodiesel combustion produces reduced carbon monoxide $\left(\mathrm{CO}_{2}\right)$ and unburned hydrocarbon (UHC) emissions, but higher nitrogen oxides (NOx) emissions. The current study is to investigate the thermal and chemical effect of exhaust gas recirculation (EGR) on features of a diesel engine for environmental sustainability. The punnai oil was produced from kernels of punnai seeds and transesterified in two phases using alcohol with the existence of a catalyst. The higher viscosity of punnai oil biodiesel is diluted by mixing it with diesel fuel. Our previous investigation indicated that neat punnai oil biodiesel is a potential fuel; however, the findings showed that the addition of diesel is necessary to obtain acceptable engine performance. In this study, punnai oil biodiesel was mixed at a rate of $20 \%$ with diesel (B20) and run in a diesel engine with varied EGR rates under five different engine loads. This combined impact enhanced the maximum heat release rate (HRR) and maximum combustion pressure, according to the findings. The premixed burning fractions were commonly higher at all engine loads, whereas the diffusion combustion fractions were lower. When the centre of the HRR changed toward the top dead centre (TDC), combustion durations remained rather constant. The experimental results revealed B20 blend at 10\% EGR flow rate produced $6.57 \%$ lower BTE, 37.04\% higher BSEC, 2.47\% higher EGT, 5.13\% lower CO, 31.11\% higher CO2, $3.13 \%$ higher UHC, $8.36 \%$ lower NOx and $4 \%$ higher smoke opacity when compared with diesel in a standard diesel engine.

\section{Introduction}

Using large volumes of petroleum derivatives like diesel causes them to go extinct in the next 30-40 years. Because of their high thermal efficiency, diesel engines have an extensive choice of uses in the transportation industry (Vijayakumar et al. 2016). According to the studies (Ramakrishnan et al. 2018; Sharma and Duraisamy 2019; Ulusoy 2020; Chatterjee et al. 2021), India is one of the major oil importers and consumers. However, diesel engines emit toxic impurities such as particulate matter, NOx, and trace levels of $\mathrm{UHC}$ and $\mathrm{CO}$, which create not just greenhouse effects that are damaging to the environment but also to humans (Kothandan and Masimalai 2018). As a result, there is an immediate need to investigate and discover substitute fuels for diesel engines. In the current scenario, vegetable oils made from seeds can partially eliminate the dependency on diesel fuel. Vegetable oils have the advantages of minimising dependency on fossil fuels, having a poor carbon content, having a low propensity to create pollutants, and being available from a variety of feedstocks (Rajasekar et al. 2020). They are decomposable and do not include harmful particles like sulphur or lead, resulting in less hazardous discharges to the environment (Zhong et al. 2021). Straight vegetable oils have operational and long-term durability issues as an effect of the low volatility, high viscosity and polyunsaturated nature of vegetable oils (FernándezTirado et al. 2021). While some biofuels have higher performance and lower emissions, their high costs have made them unpopular (Jahirul et al. 2021). Furthermore, there are certain drawbacks, like increased viscosity, decreased calorific value, and gum formation when using these oils (Rajesh et al. 2021). 
Various biofuels generated have been used in diesel engines by several researchers. A few of the biofuels have received more attention since their greater potential for renewable energy. To bring about changes, it appears that further research into biodiesel fuels is still required. In recent years, various important research using biodiesel fuel has been presented from the literature.

Rakopoulos et al. (2006) have been evaluated the use of biodiesels of cottonseed, soybean, sunflower, and olive in a diesel engine. There is a low smoke density, $\mathrm{CO}$ emissions, and a minor decrease in NOx emissions. It was reported that the lesser temperature produced by the low heating value of the fuel was the cause of the increase in $\mathrm{HC}$, whereas NOx dropped when biodiesel content was raised. Sahoo et al. (2007) have experimented with the effect of polanga biodiesel blends on $\mathrm{Cl}$ engines and concluded that the smoke and NOx emission were also better than diesel. It was concluded that it performed somewhat better than diesel in terms of BTE and BSEC due to the additional oxygen concentration in biodiesel. Devan and Mahalakshmi (2009) measured the impact of poon oil biodiesel in a diesel engine. The smoke, UHC, and CO emissions were lesser, and higher NOx emissions were reported. Besides shorter ID was noted for all fuels tested in comparison with diesel. Nabi et al. (2009) experienced diesel engines with cottonseed oil and observed that the BTE was slightly lower than diesel owing to its low calorific value, high viscosity and higher density. Furthermore, biodiesel blends emit less $\mathrm{CO}$, PM, and smoke due to the trace of oxygen in the chemical structure and reduced aromatics, with a minor increase in NOx emissions. Murugesan et al. (2009) examined the possibilities of Pongamia oil in diesel engines. While utilising biodiesel, the development of peak pressure, analysis of HRR, and engine vibration were examined. They concluded that the diesel engines exhibited low UHC, CO, NOx and particulates. Puhan et al. (2010) have discussed the monoalkyl esters of vegetable oil with different molecular weights and double bonds and their effect on the diesel engine. For unsaturated biodiesel, the HC, CO, Smoke and NOx pollutants are high when compared to highly saturated biodiesel. The biodiesel with high unsaturated linolenic fatty acid produces more NOx and low thermal efficiency. Ng and Gan (2010) have evaluated the diesel engine performance using cottonseed biodiesel at various engine loads. They recorded that the smoke, hydrocarbon emission of the B25 blend was slightly higher and the CO, NOx emissions for B25 was $4 \%$ lower at full load. Higher peak combustion pressure and smooth combustion were recorded when operating with higher blends. Roy et al. (2014) inspected diesel engines using three series of canola biodiesel blends at high idling operations. They have been observed that the biodiesel blends emit considerably less $\mathrm{CO}$ and $\mathrm{HC}$ than conventional diesel. Whereas the NOx emissions were either reduced or maintained at the same level when diesel fuel contained up to $5 \%$ canola oil biodiesel. At high idling circumstances, Rahman et al. (2017) made a detailed study on diesel engines powered with biodiesel diesel blends of palm and Calophyllum. In their results, BSEC increased, $\mathrm{CO}$ and UHC emissions for both biodiesel blends were lesser. Can (2014) has been investigated the waste cooking oil biodiesel blends in $\mathrm{Cl}$ engine. In his results, a marginal reduction in the combustion pressure, maximum HRR, and rise in combustion duration were reported. It was found that the improvement in the concentration of biodiesel increases the oxides of nitrogen and $\mathrm{CO}_{2}$ emissions and reduces the smoke and hydrocarbon emissions at the full load. Ong et al. (2011) examined the diesel engine with three different biodiesel blends at full throttle load. The $10 \%$ biodiesel blend showed better torque, power, fuel consumption and BTE and a 
substantial drop in $\mathrm{CO}_{2}, \mathrm{CO}$ and smoke emissions with a minor rise in NOx emissions. Muthukumaran et al. (2015) tried Calophyllum oil prepared by fly ash catalyst in diesel engine and noted that the BTE of B25 performed closer to diesel and reduced for higher combinations. However, NOx emission reduced and other emissions like UHC, CO and smoke were comparable with diesel. Ashok et al. (2016) experimentally evaluated the parameters of Calophyllum biodiesel and observed lower BTE with low $\mathrm{CO}$ and $\mathrm{HC}$ with a significant consequence in NOx emissions. However, the in-cylinder pressure, ID and HRR were closer to diesel. Yadav et al. (2016) studied Kusum, oleander, groundnut oil-fuelled diesel engines and showed the meagre performance to diesel. However, the $\mathrm{CO}, \mathrm{HC}$ and smoke emissions of all biodiesel were lesser and NOx emission was high.

Biodiesel is made from a variety of sources, one of which is punnai. Punnai is a non-edible oilseed in the Clusiaceae family of an evergreen tree (Arumugam and Ponnusami 2019). Though it grows occasionally inland at high altitudes, the trees are primarily planted near coastline regions and neighbouring lowland woodlands. Asia, Australia, India, and eastern Africa are all home to this species (Hazar and Sevinc 2019). Punnai thrives on sandy, well-drained soils, although it may also grow in clay, rocky, and calcareous soils (Ong et al. 2017). A dense canopy of lustrous, robust, glossy leaves, hefty spherical nuts, and fragrant white blooms cover the tree (Arumugam and Ponnusami 2014). When fully grown, the trees grow to be between 8 and 20 metres tall, with some reaching up to 35 metres (Vigneshwar et al. 2019). The tree grows around 1 metre per year in ideal conditions (Jain et al. 2018). The leaflets are glossy and hefty, with 10-20 cm length and 6-9 cm width, with a pale green colour throughout growth and dark green colour at maturity (Nanthagopal et al. 2017). Because of the following factors, biodiesel made from punnai oil is being considered as a potential alternative for traditional diesel (Ramesh Bapu et al. 2017). Punnai trees have a longer life span and are extremely susceptible to cold and fire. With a planting density of 400 trees per hectare, these trees may flourish on any type of land. With an aggregate production of $4680 \mathrm{~kg}$ of punnai oil per hectare of land, each tree can give oil at a rate of $11.7 \mathrm{~kg}$. Punnai seed oil output is discovered to be higher (about $4680 \mathrm{~L}$-oil/ha) than oil yield of Jatropha curacas (approximately $1892 \mathrm{~L}$-oil/ha). It has strong solubility with diesel and is also easy to lubricate (Marso et al. 2017). Due to its high heat value and complies with most biodiesel specifications (Mohamed Shameer and Ramesh 2017). The mix derived from Punnai has a greater ignition pressure and temperature, as well as a shorter ID; additionally, BTE, peak HRR, and power output are equivalent and similar to that of normal diesel (Kshirsagar and Anand 2017). Reformulation of biodiesel fuel compositions has been investigated in certain research as a strategy to reduce increasing NOx emissions (Venkatesan et al. 2021). When exhaust gases are recirculated, a portion of the fresh air is supplied with $\mathrm{CO}_{2}$ from the exhaust gas (Vallapudi et al. 2018). Because there is less oxygen present, the combustion temperature is lowered, which minimises the quantity of NOx (Liang et al. 2021). This allows all types of diesel engines to considerably reduce NOx emissions (Thangaraj and Govindan 2018). Cl engines running on biodiesel emit more NOx due to the improved burning of oxygenated biodiesel. Biodiesel caused advanced injection time, which enhances NOx emissions (Bakthavathsalam et al. 2019). The biodiesel-powered engine's fuel injection timing and combustion behaviour are impacted by its increased viscosity and bulk modulus are identified as a primary contributor to NOx emissions. Abd-Alla et al. (2001) explored the 
impact of EGR on the diesel engine. They thought that the admission of diluents reduces the NOx emission might be resulted due to a rise in inlet temperature. Even though a result of the shorter ID, the combustion parameters and NOx emissions improved as UHC decreased. According to their research, mixing exhaust gas with air intake lowers combustion temperatures by rising the specific heat, which substantially reduces engine performance. In another study, Zheng et al. (2004) conveyed that the reduction in flame temperature and the oxygen content by admitting EGR to the airflow decreases the NOx and increases the PM emissions. However, the rise in the EGR rate increases carbonaceous emissions and reduces power. In addition, the increased use of exhaust gases in the fresh charge has caused an imbalance in the engine framework. Finally, they concluded that a lower EGR percentage resulted in lower NOx emissions and better fuel economy. Agarwal et al. (2011) used EGR to lesser the oxygen content in the cylinder to rise the heat capacity of the suction air and reduce the temperatures of flame. The thermal efficiency slightly increased at low and peak loads owing to low flame temperatures and reduced content of oxygen. Also, they concluded that the UHC, $\mathrm{CO}$, and smoke were improved with EGR, but NOx emission decreased due to lower EGT. However, higher carbon deposits and greater piston ring wear were noticed. According to the findings of Yasin et al. (2015), diesel engines using palm biodiesel with EGR lowered the BP, torque, improved fuel consumption, lowered NOx, and had a very little rise in $\mathrm{CO}_{2}, \mathrm{CO}$, and PM emissions. Can et al. (2016) be thought that the combination of biodiesel with EGR leads to an increase in the maximum HRR and maximum CP by delaying the SOC timing with longer ID. However, the CD was almost stable when the centre of HRR shifted toward TDC due to an increase in the EGR rate. It was reported that $6 \%$ increments on the BSFC and a $3 \%$ reduction in BTE with $15 \% \mathrm{EGR}$. Further, a simultaneous improvement of 55\% NOx and 15\% smoke at full load. Sakhare et al. (2016) calculated the EGR effects on cottonseed biodiesel fuelled diesel engines and reported that the ID was shorter with B20 fuel due to higher oxygen and CN. In their results, a rise in NOx emission is reported owing to the increase in the premixed burning and a decrease in the diffusive burning with the B20 blend. It was concluded that the NOx emission was reduced by a smaller quantity of EGR gas, but a higher volume of EGR gases showed deterioration in diesel engine performance. From the results, Yasin et al. (2017) reported that the EGR makes a substantial drop in the NOx emission and EGT but rises the fuel cost. With the rise in EGR \%, Kumar et al. (2018) found a rise in BSFC and a lower BTE. It was observed that the rise in the $\mathrm{CO}$ and $\mathrm{UHC}$ emissions with the rise in EGR\%. However, the 10\% EGR decreases NOx emissions drastically.

EGR is the method often utilised in diesel engines, and it plays a key role in attempts to minimise rising NOx emissions (Sogbesan et al. 2021). It's also forced to think about the effect of EGR on combustion, engine performance, and exhaust emissions. Punnai oil biodiesel has been utilised by several researchers due to its great production and low price (Bibin et al. 2019). Normally, it was widely grown in many nations. Several researchers have also recommended using punnai oil as a biofuel (Ashok et al. 2017b). Many studies on the influence of IT and IP utilising punnai oil biodiesel in blended form have been conducted (Nanthagopal et al. 2016; Ashok et al. 2017c). However, all of these experiments focused on improving the engine's performance. However, although enhancing the engine's performance, the NOx emissions produced represent a serious threat to the environment. 
As evidenced by the literature, the application of EGR is an extensively utilised technology in diesel engines and plays an essential part in attempts to reduce rising NOx emissions. In this study, a fuel mixture such as Diesel-punnai oil biodiesel (B20) was employed as an alternative fuel in a diesel engine without requiring any engine changes. This mixture was chosen based on the previous research of the author on the same engine. According to the earlier experimental work of the author, the B20 blend might partially remove the use of diesel while maintaining optimal performance and emission characteristics (Bibin et al. 2020). The impacts of EGR on engine performance must be taken into account and evaluated. The goal of this study is to give thorough insights into the influence of combined punnai oil biodiesel and EGR on combustion, engine performance, and pollutant emissions, as well as a comparison to diesel fuel operation and find certain distinguishing characteristics. Some unique features about them have been found.

\section{Experimental Setup}

A single-cylinder diesel engine was used in this experimental investigation. Table 1 lists the test engine specifications. Figure 1 shows a schematic layout for experimental research with EGR. For measuring brake power, an eddy-current dynamometer and an electronic torque exciter with a diesel engine are used. At $1500 \mathrm{rpm}$, the eddy-current dynamometer has a rated BP of $4.4 \mathrm{~kW}$. The temperature of the exhaust gas is recorded using a digital temperature metre with thermocouples. Emissions are recorded using an exhaust gas analyser. The $\mathrm{CO}, \mathrm{CO}_{2}, \mathrm{UHC}, \mathrm{O}_{2}$, and $\mathrm{NOx}$ were observed using a five-gas exhaust analyser. A smoke meter is an instrument that measures smoke emissions. This smoke meter measured smoke by measuring the amount of light absorbed in a certain length of exhaust gas column. The filter paper method was used to calculate the Filter Smoke Number. This instrument is suitable for both heavy and light-duty engines, regardless of their generation. The pressure within the cylinder was measured using a transducer. On the crankshaft, a crank angle encoder was installed, and the in-cylinder pressure was calculated by crank angle. Table 2 lists the properties of B20 punnai oil biodiesel fuel.

Table 1

Test engine specifications

\begin{tabular}{|llll|}
\hline Make and Model & Kirloskar TAF 1 & Cylinders & One \\
\hline Cooling & Air cooling & Ignition & C.I \\
\hline Bore dia & $87.5 \mathrm{~mm}$ & Stroke & $110 \mathrm{~mm}$ \\
\hline Dynamometer & Eddy current & Compression Ratio & $17.5: 1$ \\
\hline
\end{tabular}


Table 2

Properties of B20 Punnai oil Biodiesel

\begin{tabular}{|lllll|}
\hline Properties & Unit & Diesel & B20 Biodiesel & Testing method \\
\hline Density at $25^{\circ} \mathrm{C}$ & $\mathrm{kg} / \mathrm{m}^{3}$ & 810 & 821 & ASTM D127 \\
\hline Kinematic viscosity at $40^{\circ} \mathrm{C}$ & $\mathrm{cSt}$ & 2.3 & 2.82 & ASTM D445 \\
\hline Flash point & ${ }^{\circ} \mathrm{C}$ & 55 & 76 & ASTM D93 \\
\hline Cetane number & & 45 & 46 & ASTM D6890 \\
\hline Carbon content & $\mathrm{wt} \%$ & 86.6 & 84.7 & ASTM D5291 \\
\hline Calorific Value & $\mathrm{kJ} / \mathrm{kg}$ & 42500 & 41600 & ASTM D240 \\
\hline
\end{tabular}

\section{Experimental Procedure And Uncertainty}

Experimental trials were achieved at $1500 \mathrm{rpm}$ engine speed with five engine loads. In the studies, a Punnai oil biodiesel comprising $20 \%$ by volume was injected with varied EGR rates and the results obtained were compared to diesel. EGR causes a rise in BSFC as well as $\mathrm{HC}, \mathrm{CO}$, and smoke emissions. As a result, although EGR reduces NOx emissions, it also increases smoke emissions. Engine operating with oxygenated fuel and EGR reduces NO without compromising BSFC or emissions. The recirculated exhaust gas quantity and the entire intake mixture may be used to compute EGR percentage. To minimise errors, sufficient time was given to achieve a steady-state while the emissions were being measured. Experimental repeatability eliminates random errors, leaving only instrumental faults to be evaluated. The range, accuracy and uncertainty of the instruments are provided in Table 3. The overall uncertainty was computed analytically using the following expression:

Total percentage uncertainty

= Square root of $\left\{\left(X_{1}\right)^{2}+\left(X_{2}\right)^{2}+\left(X_{3}\right)^{2}+\left(X_{4}\right)^{2}+\left(X_{5}\right)^{2}+\left(X_{6}\right)^{2}+\left(X_{7}\right)^{2}+\left(X_{8}\right)^{2}+\left(X_{9}\right)^{2}+\left(X_{10}\right)^{2}+\left(X_{11}\right)^{2}\right\}$

= square root of $\left\{(1.5)^{2}+(0.2)^{2}+(1.0)^{2}+(1.5)^{2}+(0.15)^{2}+(0.2)^{2}+(0.2)^{2}+(0.2)^{2}+(1.0)^{2}+(0.15)^{2}+(1.0)^{2}\right\}$

$= \pm 2.77 \%$

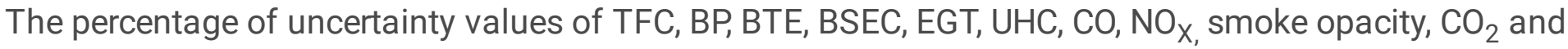
pressure pick up were mentioned as $\mathrm{X}_{1}, \mathrm{X}_{2}, \mathrm{X}_{3}, \mathrm{X}_{4}, \mathrm{X}_{5}, \mathrm{X}_{6}, \mathrm{X}_{7}, \mathrm{X}_{8}, \mathrm{X}_{9}, \mathrm{X}_{10}$ and $\mathrm{X}_{11}$ respectively. 
Table 3

The range, accuracy and uncertainty of the instruments

\begin{tabular}{|llll|}
\hline Instruments & Range & Accuracy & uncertainties \\
\hline Gas Analyzer & $\mathrm{CO}-0$ to $10 \%$ vol. & $\pm 0.02 \%$ & \pm 0.2 \\
\cline { 2 - 4 } & $\mathrm{CO}_{2}-0$ to $20 \%$ vol. & $\pm 0.03 \%$ & \pm 0.15 \\
\cline { 2 - 4 } & $\mathrm{HC}-0$ to $20000 \mathrm{ppm}$ & $\pm 15 \mathrm{ppm}$ & \pm 0.2 \\
\cline { 2 - 4 } & NOx - 0 to $5000 \mathrm{ppm}$ & $\pm 20 \mathrm{ppm}$ & \pm 0.2 \\
\hline Smoke measurement & Opacity $0-100 \%$ & \pm 0.1 & \pm 1.0 \\
\hline EGT indicator & $0-900^{\circ} \mathrm{C}$ & $\pm 1^{\circ} \mathrm{C}$ & \pm 0.15 \\
\hline Speed measurement & $0-10,000 \mathrm{ppm}$ & $\pm 10 \mathrm{rpm}$ & \pm 1.0 \\
\hline Load indicator & $0-100 \mathrm{~kg}$ & $\pm 0.1 \mathrm{~kg}$ & \pm 0.2 \\
\hline Burette & - & $\pm 0.2 \mathrm{~cm}$ & \pm 1.5 \\
\hline Stopwatch & - & $\pm 0.2 \mathrm{~s}$ & \pm 0.2 \\
\hline Manometer & - & $\pm 1 \mathrm{~mm}$ & \pm 1.0 \\
\hline Pressure pick up & $0-110 \mathrm{bar}$ & $\pm 1 \mathrm{bar}$ & \pm 0.1 \\
\hline Crank angle encoder & - & $\pm 1^{\circ}$ & \pm 0.2 \\
\hline
\end{tabular}

\section{Results And Discussions}

The engine was initially run on diesel, which served as a reference fuel. The baseline values were tested using diesel fuel at $1500 \mathrm{rpm}$ speed for several load spectrums. The fuels were supplied at $200 \mathrm{bar}$ pressure with a $23^{\circ} \mathrm{bTDC}$ injection time. The fuel was then changed to B20. Then fresh air entering was displaced by exhaust gas. The pressure of exhaust gas was less than that of scavenging air, so the EGR blower forced the recirculated exhaust gas. The quantity of EGR admitted was recorded by the orifice. Before being supplied into the combustion chamber, the entering air and recirculated exhaust gas were thoroughly mixed in the mixing chamber. The EGR rate was increased through the gradual opening of the EGR valve gradually. Various flow rates such as 5\%,10\% and 15\% EGR were admitted for the estimation of the performance of the diesel engine. However, the flow rate of EGR was not increased beyond $15 \%$. During the investigation, the in-cylinder pressure HRR, EGT and emissions parameters $\mathrm{HC}, \mathrm{CO}, \mathrm{CO}_{2}, \mathrm{NOx}$, and smoke density were recorded. Lastly, all the results attained from the diesel engine operated with $20 \%$ biodiesel blend with various EGR rates were compared with baseline diesel. The performance, combustion and emission characteristics of a diesel engine are demonstrated in the following sections with the help of graphs.

\subsection{Performance Characteristics}




\subsubsection{Brake thermal efficiency}

Figure 2 shows a comparison of BTE to BP for $B 20$ at various EGR rates. The values of $B T E$ at $0 \%, 5 \%$, $10 \%$ and $15 \%$ EGR flow rates were $28.6 \%, 28 \%, 27.4 \%$ and $26.9 \%$ respectively for B20 blend, compared to $29.2 \%$ for diesel. EGR reduces BTE at all loads in comparison with diesel and B20 fuel. The rise in EGR flow rates proportionally decreases the BTE due to the deficiency of oxygen content within the cylinder during combustion when using EGR which resulted in poor burning (Lamba et al. 2017). The lessening in combustion temperature is due to the higher heat capacity of EGR gases resulted in lower BTE.

\subsubsection{Brake specific energy consumption}

Figure 3 represents the variation of BSEC to BP for various EGR rates. The BSEC values obtained for diesel and B20 are $10.63 \mathrm{MJ} / \mathrm{kW}$ h, and $11.65 \mathrm{MJ} / \mathrm{kW}$ h respectively, whereas for $\mathrm{B} 20$ with $5 \%, 10 \%, 15 \%$ EGR is $12.9 \mathrm{MJ} / \mathrm{kW} \mathrm{h}, 14.56 \mathrm{MJ} / \mathrm{kW} \mathrm{h}$, and $16.22 \mathrm{MJ} / \mathrm{kW} \mathrm{h}$ at full throttle. When compared to diesel, the B20 blend has a high BSEC. EGR increases BSEC at all loads compared with diesel and B20 blends without EGR. The BSEC for B20 is higher than diesel for with and without EGR at all spectrum of loads.

This is due to the B20 blend mode's lower burning temperature and greater rate of fuel flow, both with and without EGR. A rise in BSEC was also assisted by lower calorific values (Rangel et al. 2021). Higher combustion temperatures and improved fuel usage result in improved fuel economy at high loads (Varuvel et al. 2018). At full throttle, The BSEC increased by $8.78 \% 17.61 \%, 27.02 \%$ and $34.51 \%$ for B20 + EGR 0\%, B20 + EGR 5\%, B20 + EGR 10\% and B20 + EGR 15\% respectively in comparison to conventional diesel fuel. Reduced oxygen concentration leads to poorer combustion, resulting in high BSEC with the rise in EGR \%.

\subsubsection{Exhaust gas temperature}

Figure 4 depicts the comparison of EGT versus BP for various EGR rates. It was reported that with the rise in load, EGT also increases. The EGT for standard diesel was $364^{\circ} \mathrm{C}$, and in the case of B20 blend with $0 \%, 5 \%, 10 \%$ and $15 \%$ EGR flow rates, it was $386^{\circ} \mathrm{C}, 380^{\circ} \mathrm{C}, 373^{\circ}$ and $368^{\circ} \mathrm{C}$ respectively at full throttle. The EGT was lower when the engine was run with EGR than when it was operated without EGR (Subramanian et al. 2018). Owing to the unavailability of oxygen due to the recirculated exhaust gases blended with fresh air in the cylinder for combustion and greater heat capacity of the admitted mixture, a rise in the rate of EGR correspondingly produced a fall in the EGT (Muniappan and Rajalingam 2018). With the induction of EGR, dilution of the working mixture lowers the peak cylinder temperature, resulting in a drop in EGT.

\subsection{Emission Characteristics}

\subsubsection{Carbon monoxide emissions}

Figure 5 shows a comparison in $\mathrm{CO}$ emission to BP for B20 blend and diesel at different EGR rates. It was noticed that $\mathrm{CO}$ emission improved for increasing EGR rates. The heterogeneous mix does not combust completely and produce high $\mathrm{CO}$ emissions. At full throttle, the $\mathrm{CO}$ emission for standard diesel was 
$0.41 \%$, and in the case of B20 blend with $0 \%, 5 \%, 10 \%$ and $15 \%$ EGR flow rates are $0.35 \%, 0.37 \%, 0.38 \%$ and $0.39 \%$ respectively. Incomplete combustion produced by the diluted mixture is most likely to blame for the CO generation (Damodharan et al. 2018). As the EGR\% rises, the fresh air is swapped by exhaust gas, and the lack of oxygen may be ascribed to an increase in $\mathrm{CO}$ emissions. Another cause of increased $\mathrm{CO}$ emission might be a rise in the $\mathrm{CO}_{2}$ concentration of the injected mixture rather than fresh air (Živković and Veljković 2018). In conclusion, it reduces combustion temperature, resulting in higher CO emissions. However, incomplete combustion owing to a rise in equivalence ratio and lesser oxidation temperatures with EGR rise at full throttle might show a substantial rise in $\mathrm{CO}$ emissions, specifically at 15\% EGR.

\subsubsection{Unburned hydrocarbon emissions}

Figure 6 depicts the comparison of UHC emissions to BP for B20 and diesel at different EGR rates. The $\mathrm{UHC}$ emissions improved with an increase in EGR percentages. This could be the result of drop-in oxygen content by the exhaust gas supplied into the cylinder resulted in partial and incomplete combustion. At full load UHC emissions for Diesel, B20 (EGR 0\%), B20 (EGR 5\%), B20 (EGR 10\%), B20 (EGR 15\%) were 64 ppm, 57 ppm, 61 ppm, 66 ppm, 68 ppm respectively. According to the findings, the percentage of UHC emissions increased as EGR increased (Sonthalia 2019). The lean mixtures are more difficult to ignite and create more UHC due to the heterogeneous nature of the mixture (Chinnasamy et al. 2019). UHC emissions increase dramatically as the EGR rate rises, implying that the combustion quality deteriorates as the EGR rate rises (Singh et al. 2019). The air is replaced by EGR in the case of EGR, and the oxygen deprivation associated with a rise in EGR \% can be attributed to an improvement in UHC emissions (Jain et al. 2019). Another cause for the rise in $\mathrm{UHC}$ emissions might be a rise in $\mathrm{CO}_{2}$ concentration in the injected mixture rather than fresh air (Kumar et al. 2019). Finally, the drops in combustion temperature might lead to improving the UHC emissions.

\subsubsection{Oxides of nitrogen emissions}

Figure 7 illustrates the difference of NOx emission to BP for B20 and diesel at different EGR rates. A portion of recirculated exhaust gas is supplied to the cylinder for acting diluents in the inlet charge. The EGR gases replace some volume of fresh air in the cylinder, lowering the oxygen concentration. When EGR \% increases, the NOx emission reduces which may be due to a drop-in temperature and oxygen rate. At full load Oxides of Nitrogen emissions for Diesel, B20 (EGR 0\%), B20 (EGR 5\%), B20 (EGR 10\%), B20 (EGR 15\%) were 1516 ppm, 1547 ppm, 1455 ppm, 1399 ppm, 1325 ppm respectively. The improvement in the EGR flow rate proportionally reduces NOx emission. The decrease in NOx emissions at peak loads is high. The increase in heat capacity of the charge by diluting the incoming air with exhaust gases leads to reducing the maximum flame temperature on the diffusive combustion lean side, resulting in lowered reaction rates and lower NOx emissions (Viswanathan et al. 2019). It enhances the heat capacity of charge, lowers the cylinder temperature for the same HRR, resulting in reduced NOx emissions because of significantly greater specific heat of triatomic gases (Bragadeshwaran et al. 2019). Because of the presence of triatomic gases in the EGR, the results showed that NOx emissions are greatly decreased with EGR adoption. The $\mathrm{CO}_{2}$ absorbs the energy generated by burning, resulting in a lower oxygen mass 
fraction in the cylinder (Balasubramanian and Lawrence 2019). NOx emissions declined dramatically due to low cylinder temperature and oxygen levels.

\subsubsection{Carbon dioxide emissions}

Figure 8 represents the comparison of $\mathrm{CO}_{2}$ emission to $\mathrm{BP}$ for $\mathrm{B} 20$ and diesel at different EGR rates. At full throttle, the $\mathrm{CO}_{2}$ emission for standard diesel was $18 \%$, and in the case of $\mathrm{B} 20$ blend with $0 \%, 5 \%, 10 \%$ and $15 \%$ EGR flow rates were $20 \%, 21.8 \%, 23.6 \%$ and $25.2 \%$ respectively. At all engine loads, $\mathrm{CO}_{2}$ emissions increased as a result of combined biodiesel and higher EGR. The proportion of $\mathrm{CO}_{2}$ added using EGR, as well as the biodiesel concentration, were shown to be controlled by engine load. The greater $\mathrm{CO}_{2}$ emissions are an indication of the reduced calorific value of B20 fuel (Perumal Venkatesan et al. 2019).

\subsubsection{Smoke emissions}

The comparison of Smoke opacity with BP for diesel and B20 with various EGR rates is depicted in Figure 9. The rise in the EGR rate resulted in somewhat higher smoke emissions than diesel. The smoke density of diesel and B20 is $50 \%, 48 \%$ respectively for normal operating conditions, whereas for B20 with $5 \%$, $10 \%$, and $15 \%$ EGR it was $51 \%, 52 \%$, and $53 \%$ respectively at full throttle. There is a proportionate rise in smoke density corresponding to the \% EGR flow rate. EGR inclusion causes lower in-cylinder temperature due to weakening of the oxygen concentration with the rise in heat capacity of the charge leading to an increase in the smoke emission (Ramalingam et al. 2019). The rise in smoke emissions is caused by the fractional replacement of air by exhaust gases, which causes unstable burning owing to the lack of oxygen required for full combustion.

\subsection{Combustion Characteristics}

\subsubsection{Cylinder pressure}

The comparison of CP with the CA for diesel and $20 \%$ punnai oil biodiesel with and without EGR is indicated in Figure 10. During combustion, the in-cylinder temperature was reduced for high EGR flow rates due to the impact of air-fuel mixture dilution and higher specific heat capacity. The most significant effect is the dilution effect on the air and fuel mixture, which rises the ID period and thus permits more mixing of the charge (Ashok et al. 2017a). It was noticed that the reduction in maximum cylinder pressure was owing to increased EGR flow rates for $20 \%$ punnai oil biodiesel at full load conditions due to the unavailability of oxygen for the burning. The average CP for B20 with $5 \%, 10 \%$ and $15 \%$ EGR is found to be 70.32 bar, 70 bar and 69.7 bar respectively, whereas for diesel and B20 without EGR is 71.4 bar and 70.9 bar respectively at full load. Because there is less oxygen available for combustion when the exhaust gas is returned to the cylinder for control of NOx emissions, the peak pressure for B20 with EGR is lowered.

\subsubsection{Heat release rate}


Figures 11 indicated the HRR variation with the CA for B20 with the EGR rate at full load. The initial rise in HRR with an improvement in EGR \% is due to the exhaust gases being cycled at a higher temperature. However, when the EGR percentage increased, the HRR reduced due to a drop in fresh air. The low oxygen and fewer chemical interactions between the fuel and the oxygen, resulting in incomplete combustion. Because of the dilution effect, which reduces the premixed combustion phase, using a high EGR rate lowers cylinder temperatures during the expansion stroke. The HRR for B20 with 5\%, 10\% and 15\% EGR is found to be $48 \mathrm{~kJ} / \mathrm{m}^{3 \circ} \mathrm{CA}, 45 \mathrm{~kJ} / \mathrm{m}^{3{ }^{\circ}} \mathrm{CA}$ and $38 \mathrm{~kJ} / \mathrm{m}^{3{ }^{\circ}} \mathrm{CA}$ respectively, whereas for diesel and $\mathrm{B} 20$ without EGR is $54 \mathrm{~kJ} / \mathrm{m}^{3 \circ} \mathrm{CA}$ and $60 \mathrm{~kJ} / \mathrm{m}^{3 \circ} \mathrm{CA}$ respectively at full throttle. The heat energy absorbed by the exhaust gases during combustion, the HRR decreased (Suski and Mader 2020). The reduction in HRR may be due to the absorption of heat by the exhaust gas during the combustion process, which consequently decreases premixed combustion and hence decreased HRR compared to diesel and B20 blends without EGR at full throttle.

\subsubsection{Cylinder Peak Pressure}

The CPP variation with the CA for diesel and B20 with various EGR rates is denoted in Figure 12. The peak cylinder pressure at a higher percentage of EGR is marginally lower than B20 at full throttle. The reduction in peak pressure for B20 with EGR may be owing to the deficiency of oxygen available for combustion in the exhaust gas and is admitted to the cylinder, for the control of the NOx and also this may be possible to improve in BTE at part load, and lower combustion temperature inside the cylinder at full throttle (Tamilvanan et al. 2021). The cylinder peak pressure for $\mathrm{B} 20$ with $5 \%, 10 \%$ and $15 \%$ EGR rates is 63.7 bar, 62.3 bar and 61.4 bar, respectively, whereas for diesel and B20 is 68.3 bar, and 67 bar respectively at full throttle.

\subsubsection{Maximum Rate of Pressure Rise}

Figure 13 shows the difference of the MRPR with BP for all fuels with and without EGR. The MRPR decreased for B20 with a rise in EGR rates. The MRPR obtained for B20 with $5 \%, 10 \%$ and $15 \%$ EGR is found to be $4.0 \mathrm{bar} /{ }^{\circ} \mathrm{CA}, 3.8 \mathrm{bar} /{ }^{\circ} \mathrm{CA}$ and $3.6 \mathrm{bar} /{ }^{\circ} \mathrm{CA}$ respectively, whereas for diesel and $\mathrm{B} 20$ without $\mathrm{EGR}$ is $4.8 \mathrm{bar} /{ }^{\circ} \mathrm{CA}$ and $4.4 \mathrm{bar} /{ }^{\circ} \mathrm{CA}$ at full throttle. This reduction is reported owing to the lack of oxygen available for burning which releases less heat energy during the combustion, which is reflected in the lower exhaust gas temperature (Mohan et al. 2019).

\subsubsection{Maximum Rate of Heat Release}

Figure 14 shows the difference of the MRHR with BP with different EGR rates. The MRHR for B20 with 5\%, $10 \%$ and $15 \%$ EGR varies from $53 \mathrm{~kJ} / \mathrm{m}^{3 \circ} \mathrm{CA}, 52 \mathrm{~kJ} / \mathrm{m}^{3 \circ} \mathrm{CA}$ and $51.5 \mathrm{~kJ} / \mathrm{m}^{3 \circ} \mathrm{CA}$ respectively, and for diesel and B20 without EGR is $56 \mathrm{~kJ} / \mathrm{m}^{3 \circ} \mathrm{CA}$ and $54 \mathrm{~kJ} / \mathrm{m}^{3 \circ} \mathrm{CA}$ at full throttle due to the absorption of heat by exhaust gas during the combustion process, resulting in decreased premixed combustion and hence decreased HRR compared to diesel and B20 blend without EGR at full throttle (Cai et al. 2021).

\subsubsection{Ignition Delay}


Figure 15 presents the ID variations with BP for diesel for different EGR rates. At no-load conditions, the ID is higher for all fuels due to the availability of more time during the SOI and the SOC. If no EGR is admitted then there is a substantial reduction in the ID at all loads due to the replacement of air with EGR, which leads to a decrease of oxygen in the exhaust gases, the ignition delay period becomes longer and the combustion becomes slower (Girardi et al. 2021). The ID for diesel and B20 biodiesel, is $17^{\circ} \mathrm{CA}$ and $16^{\circ} \mathrm{CA}$ respectively, at full load, whereas for $\mathrm{B} 20$ with $5 \%, 10 \%$ and $20 \% \mathrm{EGR}$ is found to be $16.5^{\circ} \mathrm{CA}$, $17.5^{\circ} \mathrm{CA}$ and $18^{\circ} \mathrm{CA}$ respectively.

\subsubsection{Combustion duration}

Figure 16 shows the $C D$ variation against $B P$ for all fuels with and without EGR at various loads. EGR rises the specific heat of the charge in the cylinder. As a result of improvement in specific heat due to $E G R$, the charge temperature of in-cylinder drops, and the ignition also delayed in the cycle. EGR introduces triatomic molecules like tri-atomic molecules and also affects the equivalence ratio of incylinder. This tends to lower the preignition reactions, resulting in auto-ignition of the charge and a longer CD (Baweja et al. 2021). The higher EGR rate resulted in a longer combustion duration.

\section{Conclusions}

This work quantifies the effects of B20 blend with various EGR rates like $5 \%, 10 \%$ and $15 \%$ on the performance, emission and combustion parameters of a standard diesel engine was investigated. Preliminary tests have shown that clean punnai biodiesel may quickly corrode engine components, resulting in engine failure. This disadvantage might be considerably mitigated by combining low-content biodiesel. Punnai oil's high volatility might help enhance the fuel/air mixture and, as a result, engine performance, especially under high EGR circumstances. The addition of punnai biodiesel might raise the oxygen content even further, resulting in a reduction in soot emissions. The following are the summary of the results of this experimental investigation:

The experimental results revealed B20 blend at 10\% EGR flow rate performed $4.38 \%$ lower BTE, $25 \%$ higher $\mathrm{BSEC}, 3.49 \%$ lower EGT, 11.43\% higher $\mathrm{CO}, 18 \%$ higher $\mathrm{CO}_{2}, 15.79 \%$ higher $\mathrm{UHC}, 10.58$ lower NOx and $8.33 \%$ higher smoke when compared to $\mathrm{B} 20$ blend in normal diesel engine operation. Also, found that B20 blend at 10\% EGR flow rate produced $6.57 \%$ lower BTE, 37.04\% higher BSEC, $2.47 \%$ higher EGT, $5.13 \%$ lower $\mathrm{CO}, 31.11 \%$ higher $\mathrm{CO}_{2}, 3.13 \%$ higher UHC, $8.36 \%$ lower NOx and $4 \%$ higher smoke in comparison to diesel fuel in a standard diesel engine. B20 blend at 10\% EGR flow rate offers $6.57 \%$ lower performance and $4.95 \%$ higher emission than diesel fuel on normal engine operation without EGR.

Despite the decreased calorific value of the punnai oil biodiesel, the EGR rates of $5 \%$ and $10 \%$ did not have a noticeable impact on engine performance. When the EGR was raised to a $10 \%$ rate, there was a minor improvement in BSFC and a marginal drop in BTE for all engine loads. Because of the generation of a rich mixture due to limited oxygen supply, BSFC increases as the EGR rate goes up. As the EGR rate is improved, the temperature of the exhaust gas slowly decreases. The improvements in UHC emissions were obtained using B20 biodiesel and increasing the EGR rate at low and medium loads, however, at 
high throttle, degradation occurred when the EGR rate was improved above $5 \%$. The addition of B20 biodiesel and EGR did not result in substantial variations in $\mathrm{CO}$ emissions, however, at medium and high engine loads, a 15\% EGR rate resulted in minor increases in $\mathrm{CO}$ emissions. With biodiesel additives and higher $\mathrm{EGR}, \mathrm{CO}_{2}$ emissions increased marginally for all engine loads.

With the addition of B20 biodiesel and the use of an EGR system, NOx emissions in diesel fuel combustion significantly reduced at peak loads. Also, at medium, partial, and low loads, smoke emissions were slightly above the diesel combustion, but the negative impact on NOx emissions was maintained. The results demonstrate the EGR tolerance on B20 biodiesel and provide a technique for reducing NOx emissions while minimising BSFC and smoke emissions. Lower cylinder temperature results in reduced NOx emissions and greater UHC emissions with EGR owed to the increased heat capacity of intake air and exhaust gas combination and less oxygen existence. The experimental results revealed that, with EGR, B20 (biodiesel 20\%) blend at different EGR flow rates performed closer to those of diesel. B20 blend at 10\% EGR produced closer efficiency along with decreased NOx emission in comparison with diesel. This finding will benefit people in rural areas by replacing the conventional diesel with minimal vegetable oil abundant in their neighbourhood.

\section{Declarations}

\section{Ethical Approval}

Not Applicable

\section{Consent to Participate}

Not Applicable

\section{Consent to Publish}

Not Applicable

As the data and images given in the manuscript are solely prepared by the authors.

\section{Authors Contributions}

CB prepared punnai oil biodiesel also investigated diesel engines. PKD investigated diesel engines and curated data from the study. RS is a contributor in writing original drafts, reviewing \& editing the manuscript. SM supervised the experimental study and editing in the manuscript. All authors read and approved the final manuscript

\section{Funding}

There are no funding bodies/agencies involved in this research work and is solely contributed by the authors. 


\section{Competing Interests}

The authors declare that they have no competing interests

\section{Availability of data and materials}

Not Applicable

\section{References}

1. Abd-Alla GH, Soliman HA, Badr OA, Abd-Rabbo MF (2001) Effects of diluent admissions and intake air temperature in exhaust gas recirculation on the emissions of an indirect injection dual fuel engine. Energy Convers Manag 42:1033-1045. https://doi.org/10.1016/S0196-8904(00)00072-8

2. Agarwal D, Singh SK, Agarwal AK (2011) Effect of Exhaust Gas Recirculation (EGR) on performance, emissions, deposits and durability of a constant speed compression ignition engine. Appl Energy 88:2900-2907. https://doi.org/10.1016/j.apenergy.2011.01.066

3. Arumugam A, Ponnusami V (2019) Biodiesel production from Calophyllum inophyllum oil a potential non-edible feedstock: An overview. Renew Energy 131:459-471. https://doi.org/10.1016/j.renene.2018.07.059

4. Arumugam A, Ponnusami V (2014) Biodiesel production from Calophyllum inophyllum oil using lipase producing Rhizopus oryzae cells immobilized within reticulated foams. Renew Energy 64:276-282. https://doi.org/10.1016/j.renene.2013.11.016

5. Ashok B, Nanthagopal K, Jeevanantham AK et al (2017a) An assessment of calophyllum inophyllum biodiesel fuelled diesel engine characteristics using novel antioxidant additives. Energy Convers Manag 148:935-943. https://doi.org/10.1016/j.enconman.2017.06.049

6. Ashok B, Nanthagopal K, Sakthi Vignesh D (2016) Calophyllum inophyllum methyl ester biodiesel blend as an alternate fuel for diesel engine applications. Alexandria Eng J. https://doi.org/10.1016/j.aej.2017.03.042

7. Ashok B, Nanthagopal K, Subbarao R et al (2017b) Experimental studies on the effect of metal oxide and antioxidant additives with Calophyllum Inophyllum Methyl ester in compression ignition engine. J Clean Prod 166:474-484. https://doi.org/10.1016/j.jclepro.2017.08.050

8. Ashok B, Nanthagopal K, Thundil Karuppa Raj R et al (2017c) Influence of injection timing and exhaust gas recirculation of a Calophyllum inophyllum methyl ester fuelled $\mathrm{Cl}$ engine. Fuel Process Technol 167:18-30. https://doi.org/10.1016/j.fuproc.2017.06.024

9. Bakthavathsalam S, Gounder RI, Muniappan K (2019) The influence of ceramic-coated piston crown, exhaust gas recirculation, compression ratio and engine load on the performance and emission behavior of kapok oil-diesel blend operated diesel engine in comparison with thermal analysis. Environ Sci Pollut Res 26:24772-24794. https://doi.org/10.1007/s11356-019-05678-x

10. Balasubramanian D, Lawrence KR (2019) Influence on the effect of titanium dioxide nanoparticles as an additive with Mimusops elengi methyl ester in a Cl engine. Environ Sci Pollut Res 26:16493- 
16502. https://doi.org/10.1007/s11356-019-04826-7

11. Baweja S, Trehan A, Kumar R (2021) Combustion, performance, and emission analysis of a $\mathrm{Cl}$ engine fueled with mustard oil biodiesel blended in diesel fuel. Fuel 292:120346.

https://doi.org/10.1016/j.fuel.2021.120346

12. Bibin C, Seeni Kannan P, Devan P (2020) Performance, Emission and Combustion Characteristics of a DI Diesel Engine using blends of punnai oil biodiesel and diesel as fuel. Therm Sci 24:13-25

13. Bibin C, Seeni Kannan P, Devan P, Rajesh R (2019) Performance and emission characteristics of a DI diesel engine using diestrol blends and diesel as fuel. Int J Enterp Netw Manag 10:91-108. https://doi.org/10.1504/IJENM.2019.100485

14. Bragadeshwaran A, Kasianantham N, Kaisan MU et al (2019) Influence of injection timing and exhaust gas recirculation (EGR) rate on lemon peel oil-fuelled Cl engine. Environ Sci Pollut Res 26:21890-21904. https://doi.org/10.1007/s11356-019-05369-7

15. Cai P, Zhang C, Jing Z, Chen Z (2021) Development and validation of a reduced polyoxymethylene dimethyl ether 3 - Biodiesel reaction mechanism for engine application. Fuel 291:120144. https://doi.org/10.1016/j.fuel.2021.120144

16. Can Ö (2014) Combustion characteristics, performance and exhaust emissions of a diesel engine fueled with a waste cooking oil biodiesel mixture. Energy Convers Manag 87:676-686. https://doi.org/10.1016/j.enconman.2014.07.066

17. Can Ö, Öztürk E, Solmaz H et al (2016) Combined effects of soybean biodiesel fuel addition and EGR application on the combustion and exhaust emissions in a diesel engine. Appl Therm Eng 95:115124. https://doi.org/10.1016/j.applthermaleng.2015.11.056

18. Chatterjee R, Mukherjee SK, Paul B, Chattopadhyaya S (2021) Comparative spectroscopic analysis, performance and emissions evaluation of Madhuca longifolia and Jatropha curcas produced biodiesel. Environ Sci Pollut Res 28:62444-62460. https://doi.org/10.1007/s11356-021-15081-0

19. Chinnasamy C, Tamilselvam P, Ranjith $R$ (2019) Influence of aluminum oxide nanoparticle with different particle sizes on the working attributes of diesel engine fueled with blends of diesel and waste plastic oil. Environ Sci Pollut Res 26:29962-29977. https://doi.org/10.1007/s11356-01906139-1

20. Damodharan D, Sathiyagnanam AP, Rajesh Kumar B, Ganesh KC (2018) Cleaner emissions from a DI diesel engine fueled with waste plastic oil derived from municipal solid waste under the influence of n-pentanol addition, cold EGR, and injection timing. Environ Sci Pollut Res 25:13611-13625. https://doi.org/10.1007/s11356-018-1558-5

21. Devan PK, Mahalakshmi NV (2009) Study of the performance, emission and combustion characteristics of a diesel engine using poon oil-based fuels. Fuel Process Technol 90:513-519. https://doi.org/10.1016/j.fuproc.2009.01.009

22. Fernández-Tirado F, Parra-López C, Romero-Gámez M (2021) A multi-criteria sustainability assessment for biodiesel alternatives in Spain: Life cycle assessment normalization and weighting. Renew Energy 164:1195-1203. https://doi.org/10.1016/j.renene.2020.10.145 
23. Girardi JC, Bariccatti RA, de Souza SNM et al (2021) Natural compounds as antifreeze additives to improve babassu biodiesel. Fuel 289:119746. https://doi.org/10.1016/j.fuel.2020.119746

24. Hazar H, Sevinc H (2019) Investigation of the effects of pre-heated linseed oil on performance and exhaust emission at a coated diesel engine. Renew Energy 130:961-967. https://doi.org/10.1016/j.renene.2018.07.003

25. Jahirul MI, Rasul MG, Brown RJ et al (2021) Investigation of correlation between chemical composition and properties of biodiesel using principal component analysis (PCA) and artificial neural network (ANN). Renew Energy 168:632-646. https://doi.org/10.1016/j.renene.2020.12.078

26. Jain M, Chandrakant U, Orsat V, Raghavan V (2018) A review on assessment of biodiesel production methodologies from Calophyllum inophyllum seed oil. Ind Crops Prod 114:28-44. https://doi.org/10.1016/j.indcrop.2018.01.051

27. Jain NL, Soni SL, Poonia MP et al (2019) A durability study of a compression ignition engine operating with Thumba (Citrullus colocyntis) vegetable oil. Environ Sci Pollut Res 26:8992-9004. https://doi.org/10.1007/s11356-019-04237-8

28. Kothandan A, Masimalai S (2018) Cleaner emissions from a DI-diesel engine fueled with mahua oil and low carbon ethanol-hydrogen in dual fuel mode. Environ Sci Pollut Res 25:32684-32693. https://doi.org/10.1007/s11356-018-3166-9

29. Kshirsagar CM, Anand R (2017) Artificial neural network applied forecast on a parametric study of Calophyllum inophyllum methyl ester-diesel engine out responses. Appl Energy 189:555-567. https://doi.org/10.1016/j.apenergy.2016.12.045

30. Kumar AN, Brahma Raju K, Srinivas Kishore P, Narayana K (2018) Some Experimental Studies on effect of Exhaust-Gas Recirculation on Performance and Emission characteristics of a CompressionIgnition engine fuelled with Diesel and Lemon-peel oil Blends. Mater Today Proc 5:6138-6148. https://doi.org/10.1016/j.matpr.2017.12.220

31. Kumar AN, Kishore PS, Raju KB et al (2019) Engine parameter optimization of palm oil biodiesel as alternate fuel in $\mathrm{Cl}$ engine. Environ Sci Pollut Res 26:6652-6676. https://doi.org/10.1007/s11356018-04084-z

32. Lamba N, Gupta K, Modak JM, Madras G (2017) Biodiesel synthesis from Calophyllum inophyllum oil with different supercritical fluids. Bioresour Technol 241:767-774. https://doi.org/10.1016/j.biortech.2017.06.027

33. Liang J, Zhang Q, Chen Z, Zheng Z (2021) The effects of EGR rates and ternary blends of biodiesel/n-pentanol/diesel on the combustion and emission characteristics of a CRDI diesel engine. Fuel 286:119297. https://doi.org/10.1016/j.fuel.2020.119297

34. Marso TMM, Kalpage CS, Udugala-Ganehenege MY (2017) Metal modified graphene oxide composite catalyst for the production of biodiesel via pre-esterification of Calophyllum inophyllum oil. Fuel 199:47-64. https://doi.org/10.1016/j.fuel.2017.01.004

35. Mohamed Shameer P, Ramesh K (2017) FTIR assessment and investigation of synthetic antioxidant on the fuel stability of Calophyllum inophyllum biodiesel. Fuel 209:411-416. 
https://doi.org/10.1016/j.fuel.2017.08.006

36. Mohan SV, Rohit MV, Subhash GV et al (2019) Algal oils as biodiesel, Second Edi. Elsevier B.V.

37. Muniappan K, Rajalingam M (2018) TOPSIS-based parametric optimization of compression ignition engine performance and emission behavior with bael oil blends for different EGR and charge inlet temperature. Environ Sci Pollut Res 25:19040-19053. https://doi.org/10.1007/s11356-018-2048-5

38. Murugesan A, Umarani C, Subramanian R, Nedunchezhian N (2009) Bio-diesel as an alternative fuel for diesel engines-A review. Renew Sustain Energy Rev 13:653-662.

https://doi.org/10.1016/j.rser.2007.10.007

39. Muthukumaran N, Saravanan CG, Prasanna Raj Yadav S et al (2015) Synthesis of cracked Calophyllum inophyllum oil using fly ash catalyst for diesel engine application. Fuel 155:68-76. https://doi.org/10.1016/j.fuel.2015.04.014

40. Nabi MN, Rahman MM, Akhter MS (2009) Biodiesel from cotton seed oil and its effect on engine performance and exhaust emissions. Appl Therm Eng 29:2265-2270.

https://doi.org/10.1016/j.applthermaleng.2008.11.009

41. Nanthagopal K, Ashok B, Karuppa Raj RT (2016) Influence of fuel injection pressures on Calophyllum inophyllum methyl ester fuelled direct injection diesel engine. Energy Convers Manag 116:165-173. https://doi.org/10.1016/j.enconman.2016.03.002

42. Nanthagopal K, Ashok B, Tamilarasu A et al (2017) Influence on the effect of zinc oxide and titanium dioxide nanoparticles as an additive with Calophyllum inophyllum methyl ester in a $\mathrm{Cl}$ engine. Energy Convers Manag 146:8-19. https://doi.org/10.1016/j.enconman.2017.05.021

43. Ng HK, Gan S (2010) Combustion performance and exhaust emissions from the non-pressurised combustion of palm oil biodiesel blends. Appl Therm Eng 30:2476-2484.

https://doi.org/10.1016/j.applthermaleng.2010.06.020

44. Ong HC, Mahlia TMI, Masjuki HH, Norhasyima RS (2011) Comparison of palm oil, Jatropha curcas and Calophyllum inophyllum for biodiesel: A review. Renew Sustain Energy Rev 15:3501-3515. https://doi.org/10.1016/j.rser.2011.05.005

45. Ong ZC, Mohd Mishani MB, Chong WT et al (2017) Identification of optimum Calophyllum inophyllum bio-fuel blend in diesel engine using advanced vibration analysis technique. Renew Energy 109:295-304. https://doi.org/10.1016/j.renene.2017.03.039

46. Perumal Venkatesan E, Kandhasamy A, Sivalingam A et al (2019) Performance and emission reduction characteristics of cerium oxide nanoparticle-water emulsion biofuel in diesel engine with modified coated piston. Environ Sci Pollut Res 26:27362-27371. https://doi.org/10.1007/s11356019-05773-z

47. Puhan S, Saravanan N, Nagarajan G, Vedaraman N (2010) Effect of biodiesel unsaturated fatty acid on combustion characteristics of a DI compression ignition engine. Biomass Bioenergy 34:10791088. https://doi.org/10.1016/j.biombioe.2010.02.017

48. Rahman MA, Ruhul AM, Aziz MA, Ahmed R (2017) Experimental exploration of hydrogen enrichment in a dual fuel $\mathrm{Cl}$ engine with exhaust gas recirculation. Int J Hydrogen Energy 42:5400-5409. 
https://doi.org/10.1016/j.ijhydene.2016.11.109

49. Rajasekar V, Geo VE, Martin LJ, Nagalingam B (2020) The combined effect of low viscous biofuel and EGR on NO-smoke tradeoff in a biodiesel engine-an experimental study. Environ Sci Pollut Res 27:17468-17480. https://doi.org/10.1007/s11356-019-05449-8

50. Rajesh K, Natarajan MP, Devan PK, Ponnuvel S (2021) Coconut fatty acid distillate as novel feedstock for biodiesel production and its characterization as a fuel for diesel engine. Renew Energy 164:1424-1435. https://doi.org/10.1016/j.renene.2020.10.082

51. Rakopoulos CD, Antonopoulos KA, Rakopoulos DC et al (2006) Comparative performance and emissions study of a direct injection Diesel engine using blends of Diesel fuel with vegetable oils or bio-diesels of various origins. Energy Convers Manag 47:3272-3287. https://doi.org/10.1016/j.enconman.2006.01.006

52. Ramakrishnan M, Rathinam TM, Viswanathan K (2018) Comparative studies on the performance and emissions of a direct injection diesel engine fueled with neem oil and pumpkin seed oil biodiesel with and without fuel preheater. Environ Sci Pollut Res 25:4621-4631. https://doi.org/10.1007/s11356-017-0838-9

53. Ramalingam K, Kandasamy A, Balasubramanian D et al (2019) Forcasting of an ANN model for predicting behaviour of diesel engine energised by a combination of two low viscous biofuels. Environ Sci Pollut Res. https://doi.org/10.1007/s11356-019-06222-7

54. Ramesh Bapu BR, Saravanakumar L, Durga Prasad B (2017) Effects of combustion chamber geometry on combustion characteristics of a DI diesel engine fueled with calophyllum inophyllum methyl ester. J Energy Inst 90:82-100. https://doi.org/10.1016/j.joei.2015.10.004

55. Rangel NVP, da Silva LP, Pinheiro VS et al (2021) Effect of additives on the oxidative stability and corrosivity of biodiesel samples derived from babassu oil and residual frying oil: An experimental and theoretical assessment. https://doi.org/10.1016/j.fuel.2020.119939. Fuel 289:

56. Roy MM, Wang W, Alawi M (2014) Performance and emissions of a diesel engine fueled by biodieseldiesel, biodiesel-diesel-additive and kerosene-biodiesel blends. Energy Convers Manag 84:164-173. https://doi.org/10.1016/j.enconman.2014.04.033

57. Sahoo PK, Das LM, Babu MKG, Naik SN (2007) Biodiesel development from high acid value polanga seed oil and performance evaluation in a $\mathrm{Cl}$ engine. Fuel 86:448-454. https://doi.org/10.1016/j.fuel.2006.07.025

58. Sakhare NM, Shelke PS, Lahane S (2016) Experimental Investigation of Effect of Exhaust Gas Recirculation and Cottonseed B20 Biodiesel Fuel on Diesel Engine. Procedia Technol 25:869-876. https://doi.org/10.1016/j.protcy.2016.08.195

59. Sharma V, Duraisamy G (2019) Production and characterization of bio-mix fuel produced from the mixture of raw oil feedstock, and its effects on performance and emission analysis in DICl diesel engine. Environ Sci Pollut Res 26:16742-16761. https://doi.org/10.1007/s11356-019-04958-w

60. Singh Y, Sharma A, Singla A (2019) Non-edible vegetable oil-based feedstocks capable of biolubricant production for automotive sector applications-a review. Environ Sci Pollut Res 26:14867- 
14882. https://doi.org/10.1007/s11356-019-05000-9

61. Sogbesan O, Garner CP, Davy MH (2021) The effects of increasing FAME biodiesel content on combustion characteristics and $\mathrm{HC}$ emissions in high-EGR low temperature combustion. Fuel 302:121055. https://doi.org/10.1016/j.fuel.2021.121055

62. Sonthalia A (2019) Comparison of fuel characteristics of hydrotreated waste cooking oil with its biodiesel and fossil diesel. Environ Sci Pollut Res

63. Subramanian T, Varuvel EG, Ganapathy $S$ et al (2018) Role of fuel additives on reduction of NOX emission from a diesel engine powered by camphor oil biofuel. Environ Sci Pollut Res 25:1536815377. https://doi.org/10.1007/s11356-018-1745-4

64. Suski CA, Mader MM (2020) NOx and CO gas emissions in collective transport buses to diesel S50 and S10 with EGR system added with dienitro. Environ Sci Pollut Res 27:16686-16693. https://doi.org/10.1007/s11356-020-08108-5

65. Tamilvanan A, Balamurugan K, Ashok B et al (2021) Effect of diethyl ether and ethanol as an oxygenated additive on Calophyllum inophyllum biodiesel in $\mathrm{Cl}$ engine. Environ Sci Pollut Res 28:33880-33898. https://doi.org/10.1007/s11356-020-10624-3

66. Thangaraj S, Govindan N (2018) Investigating the pros and cons of browns gas and varying EGR on combustion, performance, and emission characteristics of diesel engine. Environ Sci Pollut Res 25:422-435. https://doi.org/10.1007/s11356-017-0369-4

67. Ulusoy Y (2020) Investigation of particulate matter by FTIR, TEM and elemental analyses in a diesel engine operating on diesel and waste cooking oil-biodiesel. Environ Sci Pollut Res 27:500-509. https://doi.org/10.1007/s11356-019-06741-3

68. Vallapudi DR, Makineni HK, Pisipaty SK, Venu H (2018) Combined impact of EGR and injection pressure in performance improvement and NOx control of a DI diesel engine powered with tamarind seed biodiesel blend. Environ Sci Pollut Res 25:36381-36393. https://doi.org/10.1007/s11356-0183540-7

69. Varuvel EG, Sonthalia A, Subramanian T, Aloui F (2018) NOx-smoke trade-off characteristics of minor vegetable oil blends synergy with oxygenate in a commercial $\mathrm{Cl}$ engine. Environ Sci Pollut Res 25:35715-35724. https://doi.org/10.1007/s11356-018-3484-y

70. Venkatesan V, Nallusamy N, Nagapandiselvi P (2021) Performance and emission analysis on the effect of exhaust gas recirculation in a tractor diesel engine using pine oil and soapnut oil methyl ester. Fuel 290:120077. https://doi.org/10.1016/j.fuel.2020.120077

71. Vigneshwar V, Krishnan SY, Kishna RS et al (2019) Comprehensive review of Calophyllum inophyllum as a feasible alternate energy for $\mathrm{Cl}$ engine applications. Renew Sustain Energy Rev 115:109397. https://doi.org/10.1016/j.rser.2019.109397

72. Vijayakumar C, Ramesh M, Murugesan A et al (2016) Biodiesel from plant seed oils as an alternate fuel for compression ignition engines-a review. Environ Sci Pollut Res 23:24711-24730. https://doi.org/10.1007/s11356-016-7754-2 
73. Viswanathan K, Balasubramanian D, Subramanian T, Varuvel EG (2019) Investigating the combined effect of thermal barrier coating and antioxidants on pine oil in DI diesel engine. Environ Sci Pollut Res. https://doi.org/10.1007/s11356-019-04649-6

74. Yadav AK, Khan ME, Dubey AM, Pal A (2016) Performance and emission characteristics of a transportation diesel engine operated with non-edible vegetable oils biodiesel. Case Stud Therm Eng 8:236-244. https://doi.org/10.1016/j.csite.2016.08.001

75. Yasin MHM, Mamat R, Yusop AF et al (2015) Effects of Exhaust Gas Recirculation (EGR) on a Diesel Engine fuelled with Palm-biodiesel. Energy Procedia 75:30-36. https://doi.org/10.1016/j.egypro.2015.07.131

76. Yasin MHM, Mamat R, Yusop AF et al (2017) Study of a Diesel Engine Performance with Exhaust Gas Recirculation (EGR) System Fuelled with Palm Biodiesel. Energy Procedia 110:26-31

77. Zheng M, Reader GT, Hawley JG (2004) Diesel engine exhaust gas recirculation--a review on advanced and novel concepts. Energy Convers Manag 45:883-900. https://doi.org/10.1016/S01968904(03)00194-8

78. Zhong L, Jiao X, Hu H et al (2021) Activated magnetic lipase-inorganic hybrid nanoflowers: A highly active and recyclable nanobiocatalyst for biodiesel production. Renew Energy 171:825-832. https://doi.org/10.1016/j.renene.2021.02.155

79. Živković S, Veljković M (2018) Environmental impacts the of production and use of biodiesel. Environ Sci Pollut Res 25:191-199. https://doi.org/10.1007/s11356-017-0649-z

\section{Figures}

\section{Figure 1}

\section{Experimental setup with EGR}




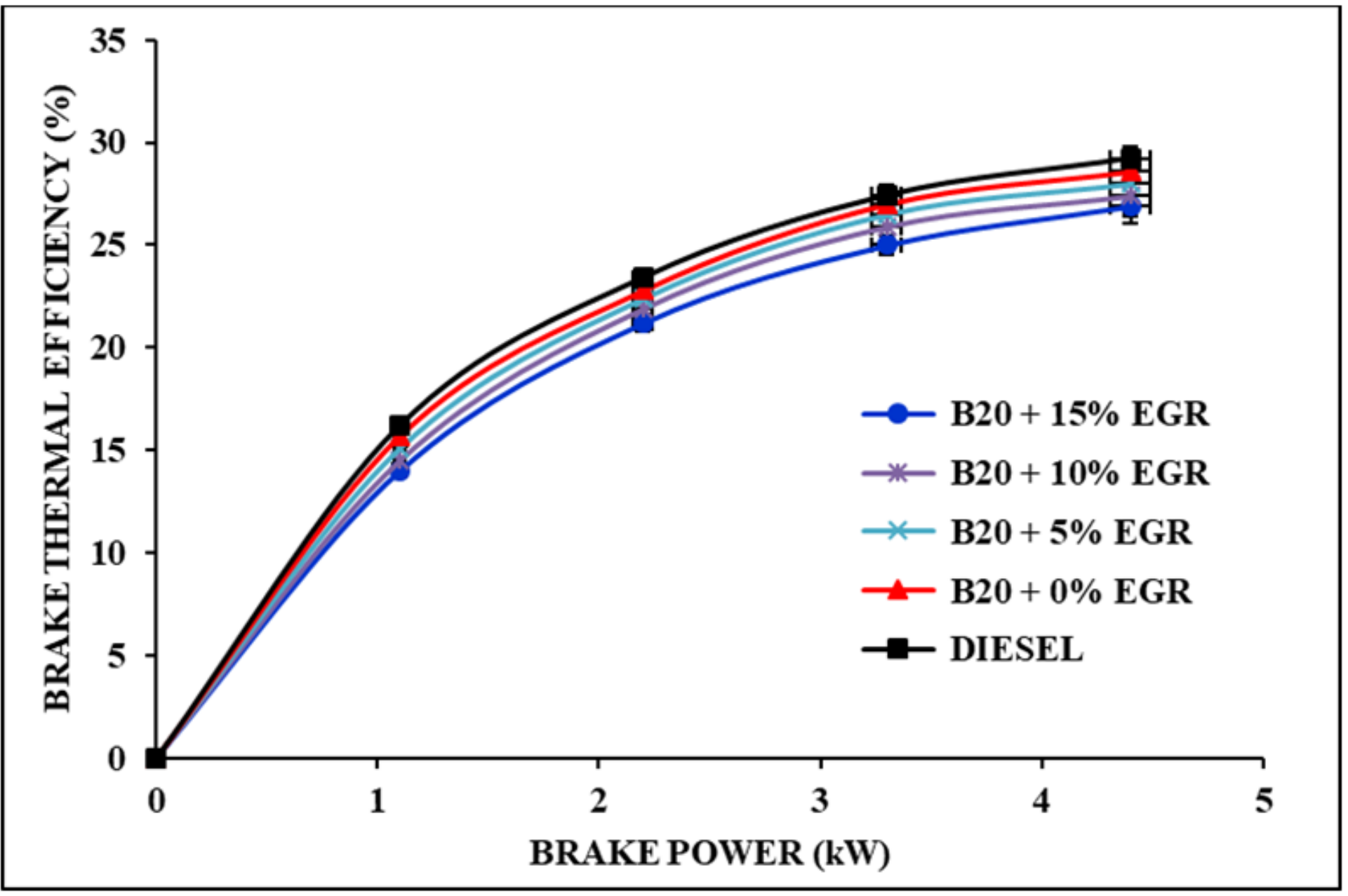

Figure 2

The comparative plot of BTE versus BP at all loads 


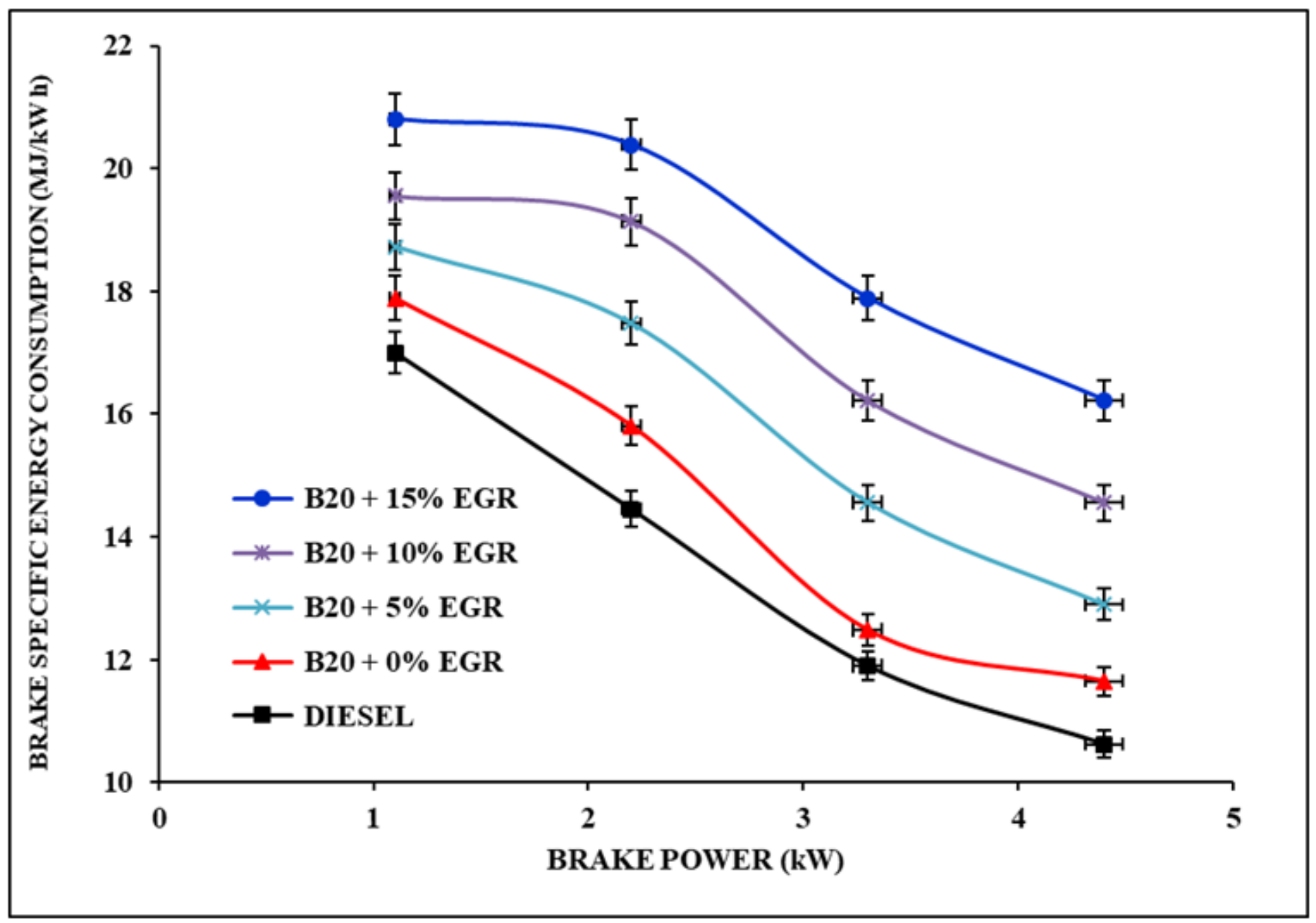

Figure 3

The comparative plot of brake specific energy consumption versus brake power at all loads

Figure 4

The comparative plot of EGT versus BP at all loads 


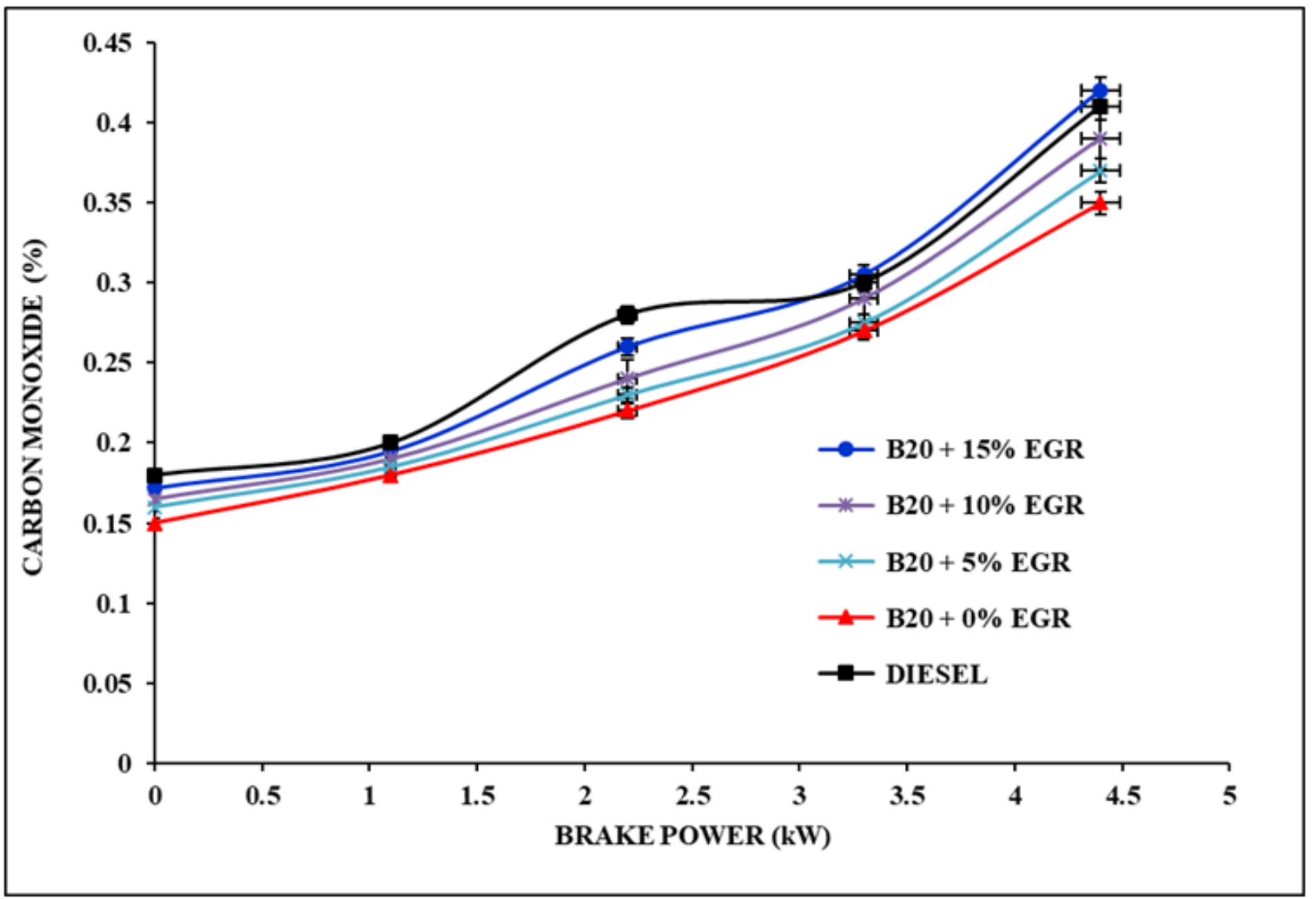

Figure 5

The comparative plot of $\mathrm{CO}$ emissions versus brake power at all loads 


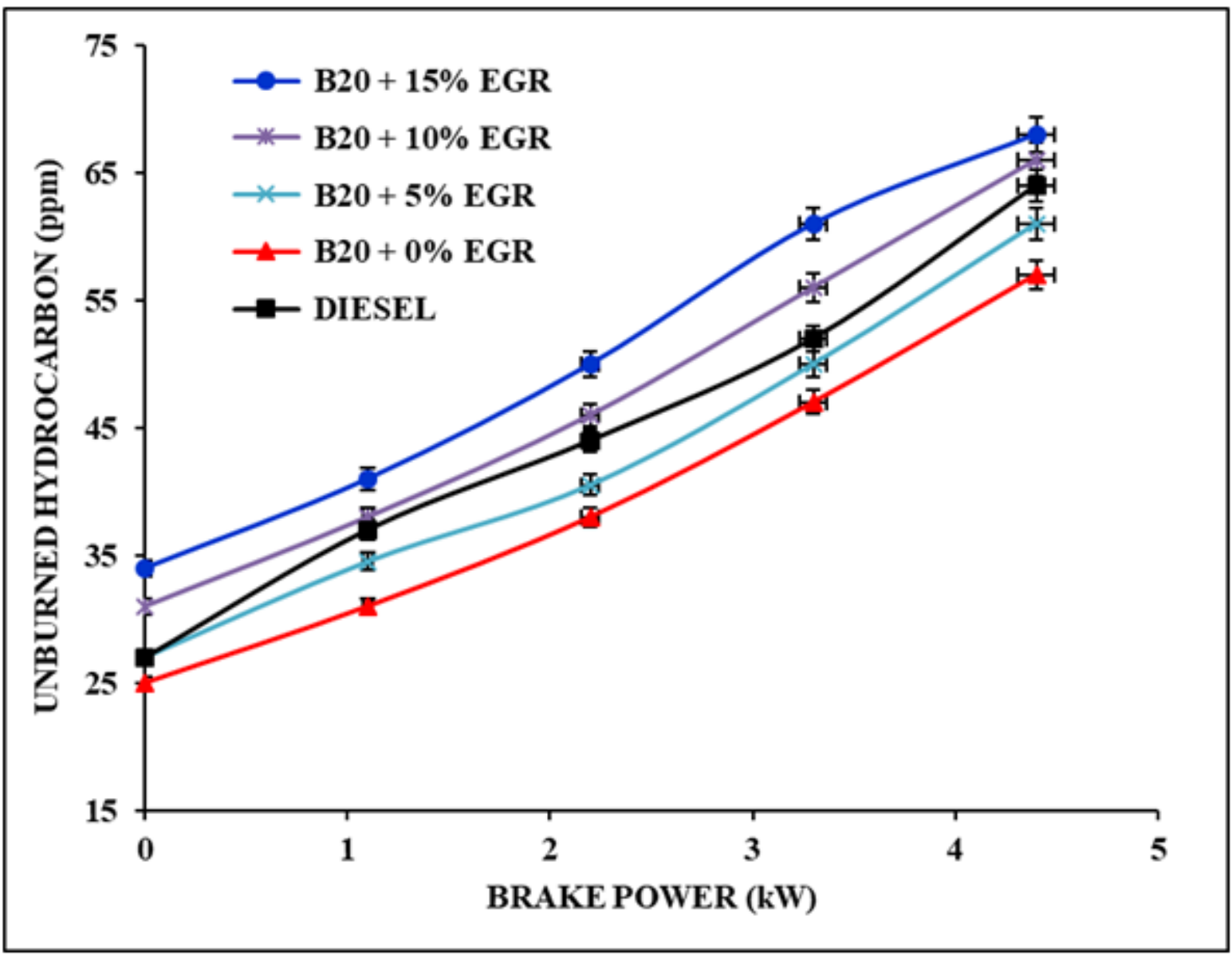

Figure 6

The comparative plot of UHC emissions versus BP at all loads

Figure 7

The comparative plot of NOx emissions and BP at all loads

Figure 8

The comparative plot of $\mathrm{CO}_{2}$ emissions versus brake power at all loads

Figure 9 
The comparative plot of smoke emissions versus BP at all loads

Figure 10

The comparative plot of $\mathrm{CP}$ versus $\mathrm{CA}$ at full load

Figure 11

The comparative plot of HRR versus crank angle at full load

Figure 12

The comparative plot of CPP versus Brake power at different loads

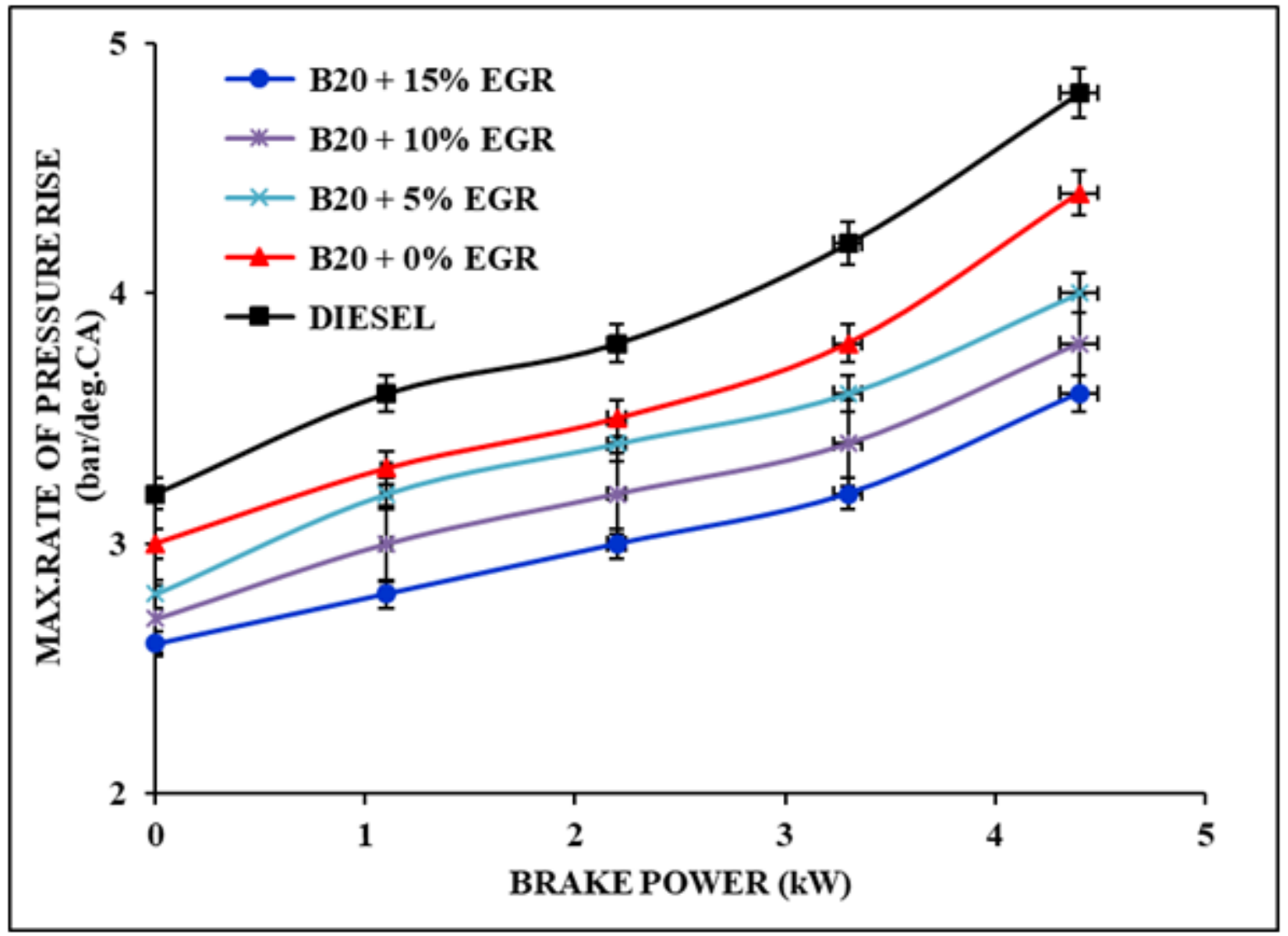


Figure 13

The comparative plot of the MRPR versus BP at different loads

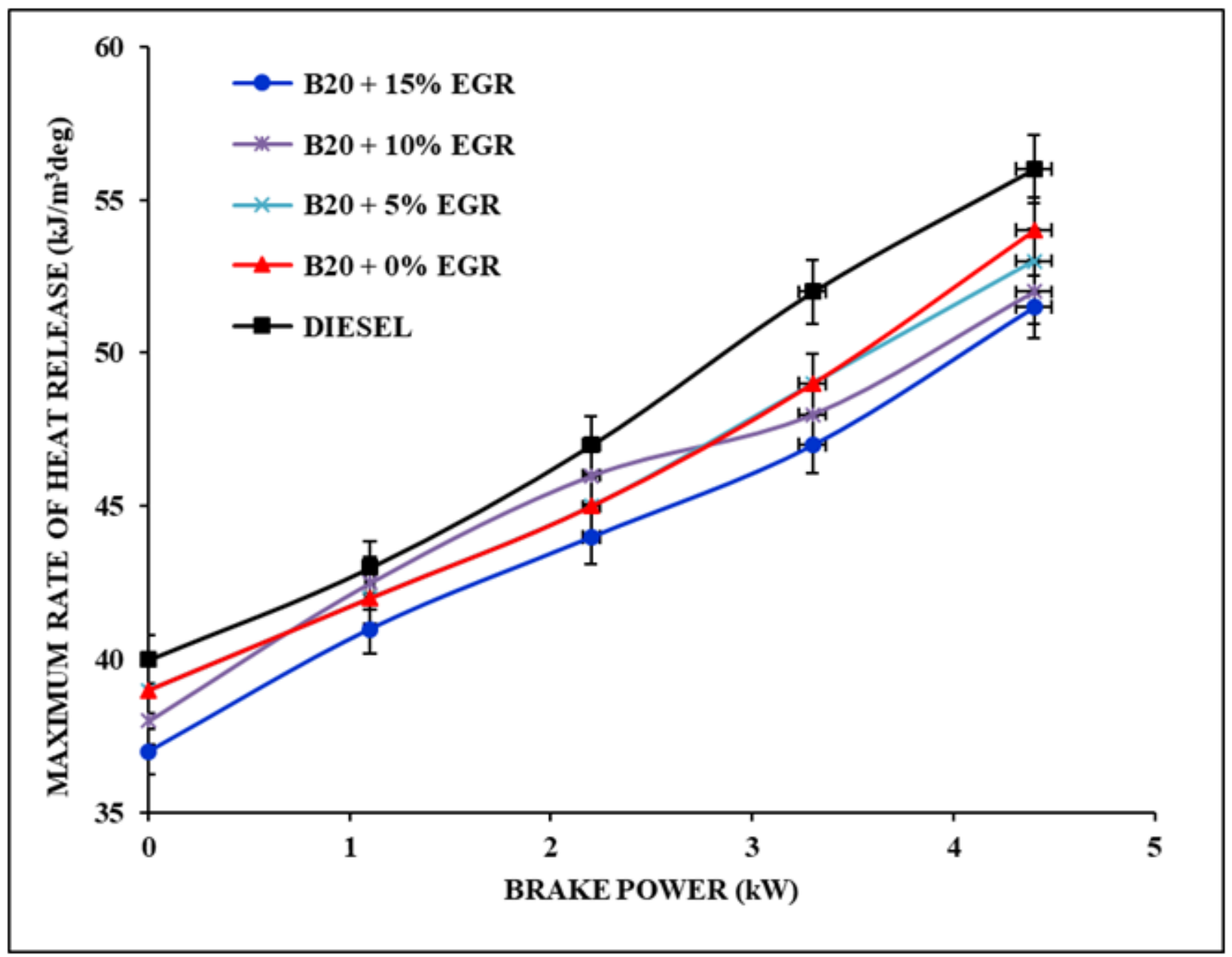

Figure 14

The comparative plot of the MRHR versus BP at different loads

Figure 15

The comparative plot of Ignition delay versus Brake power at different loads

Figure 16

The comparative plot of $C D$ versus $B P$ at different loads 